\title{
An Empirical Research on the Factors Determining Economic Literacy Level
}

\author{
Murat TEKBAŞ
}

DOI: $10.24818 / \mathrm{mer} / 2021.06-08$

\begin{abstract}
Economic literacy, which is explained as being able to interpret economic events and developments, and having a basic level of economic knowledge, becomes more and more important every day. In the globalizing world, it is seen that the economic decision-making processes of individuals who have consumer, producer and investor roles have diversified and become more complex. In this diverse and complex decision-making process, individuals' economic knowledge levels affect the decisions to be made. In this direction, the decisions taken by individuals become more important for both their own wealth and the economies of the country. Survey of individuals living in Turkey for over 385 people in the framework of the aforementioned considerations in this study to determine the level of economic literacy is made. When the answers given by the participants are evaluated, it is seen that the level of economic literacy is sufficient. When the effect of demographic factors on economic literacy is examined in the study, there is no statistically significant difference according to gender, age, marital status and income level, it is seen that the differentiation is significant according to education level and occupation groups. Within the framework of the findings obtained as a result of the study, it is considered that making economics education more widespread and providing access to information with the cooperation of universities and economic institutions will be beneficial in increasing the level of economic literacy.
\end{abstract}

KEYWORDS: economic literacy, economic education, role of economics, sociology of economics, general economics

JEL CLASSIFICATION: $A 29, A 20, A 11, A 14, A 10$

\section{INTRODUCTION}

Minimal knowledge of economics is needed to understand current economic, political and social developments. It is important to know how the economy works. Because every important event that is decisive in our lives must have an economic aspect. Economic science, a way to find solutions to economic problems; unemployment, inflation, recession, crisis, deficit, identify the internal and external economic events-such as why these events have emerged, in the future, predicts under what conditions that could occur, and what kind of measures should be taken recommends solutions (Yildirim, 2019). In the historical process, countries have made great efforts to solve macroeconomic problems. But with globalization, new opportunities and threats to economic problems have emerged.

\footnotetext{
* This study was presented at the "Alternative Paths for Development of Emerging Economies in Global Business Environment" congress in 2020 and published as a summary paper.

${ }^{1}$ Lecturer, PhD Afyon Kocatepe University, Bayat Vocational School Department of Foreign Trademtekbas @ aku.edu.tr, https://orcid.org/0000-0003-2589-2482
} 
Globalization is expressed as the integration of national countries' economies into global markets and the determination of all the economic decision processes gradually through the dynamics of world capitalism oriented to capital accumulation (Yeldan, 2016). In addition, globalization also refers to the increasing similarity in economic integration and consumption habits in terms of goods, services and capital markets among all countries that are becoming more similar to each other in individual and social respects in recent years (Aydemir \&Kaya, 2007).

The spread of globalization makes economic decisions more important for both individuals and countries. In this regard, it is considered that individuals' economic literacy levels are effective in their decisions. Economic literacy is the evaluation of different options encountered in order to evaluate and solve economic problems and to make a profit and cost analysis according to the changes in economic policy and economic conditions (Gerek \& Kurt, 2011). In this regard, many studies have been conducted on economic literacy and it has been revealed that individuals with a high level of economic literacy can understand and interpret the applied economic policies more accurately (Yasmin et al, 2014; Gök, 2020).

There are different views on the definition of economic literacy, and in general, it is defined as a review of different options in the interpretation and resolution of economic problems. Cost and profit also the recognition of changes in economic conditions and public policies, review the results of economic data collection and organizing, interpretation of economic developments and situations that may occur as a result of these developments in the form of definitions are often used. In this direction, economic literacy can be defined as the skills set out to know the basic economic concepts, understand, interpret and produce solutions to the economic situation and problems encountered. Although there are many definitions in explaining the concept of economic literacy, it seems that the main focus is on understanding, interpreting and making decisions about economic events encountered in definitions. People with economic literacy skills can act rationally in the face of economic situations that they will face in real life and create solutions to problems (Dilek et al, 2016; Gerek \& Kurt, 2011; Kahya \& İmamoğlu, 2015; Yayar \& Karaca, 2017).

It is accepted that economically literate individuals have characteristics such as being able to make cost-benefit analysis, to determine the motives that affect human behaviour, to master the interaction between supply and demand, know the duties of economic organizations, to monitor and evaluate macroeconomic indicators in roles such as consumer, producer, investor (Ünal et al., 2015).Being economically literate affects the saving-spending behaviour of individuals both as a consumer and as a producer, and this causes changes in their wealth. These decisions also have significant effects on the national economy and induce indirect effects such as the development and efficiency of the financial system, the savings rate and the pension system (Bariş \& Şeker, 2017).

In today's information age, it is seen that people's interest in economic problems increases due to the increase in access to information and the rapid spread of information. But supporting this interest with knowledge is seen as important in terms of decisions to be made. For example, knowing what economic growth is, which is the most basic economic goal, will allow a person to pursue ideas through the opportunities that will occur after economic growth. In other respects, inflation, unemployment, interest rates, external deficit, etc. it is seen that individuals who have basic knowledge of such economic issues can make their demands and decisions in the light of this information. 
Technological developments in recent years allow consumers to evaluate national and international options in their purchasing processes and make decisions accordingly. When this is evaluated from the point of view of producers, it shows that producers are in competition with producers in other countries in cost, price and Sunday, and investors have to monitor global markets, not just developments within the country. For this reason, options are increasing in the economic decisions of individuals and decision-making processes are becoming more complex. Given these considerations, supply, demand, inflation, interest rate, economic growth, etc.in the economic decision-making process. It is seen that teaching basic economics knowledge to individuals within a specific academic framework within the framework of concepts is important for individuals and the economies of the country.

Based on this, it is important to determine the level of economic literacy of individuals and develop policies accordingly to understand, interpret and make the right decisions about economic events that are becoming more complex every day. In our study, it is aimed to determine the level of economic literacy of individuals in Turkey by taking these considerations into account. In addition, the study will investigate whether the level of economic literacy shows differentiation in terms of demographic variables. For this purpose, a survey was conducted for 385 people living in different provinces, consisting of public and private sector employees, self-employed, retirees, and students. Numerous studies on the determination of the level of economic literacy in the literature (Gerek \& Kurt, 2011; Mercan et al., 2012; Yasmin et al. 2014; Unal et al., 2015; Teyyare et al., 2017; Dilek et al., 2019; Nizam et al. 2020). Studies are mostly focused on specific groups of students. This indicates that studies contain results within the scope of people with the same level of Education. In order to evaluate different segments of society, our study differs from previous studies in terms of researching people with different levels of education, age groups and income groups.

\section{LITERATURE REVIEW}

Individuals make a large number of decisions on economic issues at every stage of their lives, and the accuracy of these decisions is becoming increasingly important. Accordingly, the number of studies measuring the level of economic knowledge of individuals increases significantly. It is possible to collect these studies under three main headings.

The first is the topic of Islamic Financial Literacy, which has been focused specifically in recent years. Bekereci et al. (2019) a survey conducted with 640 students at Kahramanmaraş Sütçü Imam University concluded that the size of the financial practice is positively related to the perception of religiosity in a behavioral context. As part of the study, it is recommended that individuals with religious knowledge raise their level of financial knowledge. In another study on the same subject, Altundere Doğan (2020) investigated the level of Islamic financial literacy of 363 students studying at Sabahattin Zaim University in Istanbul. As a result of the study, it was found that the students who participated in the study had low levels of Islamic financial literacy, and some did not have sufficient knowledge.

Secondly, the focus of the studies is on financial literacy. Acaravci and Bediroğlu (2019), one of the coded studies where the financial literacy level should be determined, found that the practical financial literacy level in the Hatay Mustafa Kemal University tests was medium. The image of some mathematical problems used by Bağci and Arabaci (2019) for students of the Faculty of Economics and Administrative Sciences of Aksaray University shows that their financial literacy levels are low. Doğan (2019) states that the financial literacy level is approximately $53 \%$ in 25 different provinces, where the private and public sector employees, 
retirees and others are included in 2300 people and the results are gender, marital status, age, etc. It shows that it differs according to demographic variables.

Thirdly, the subject of our studies is economic literacy, which is also the subject of our study. Gerek\& Kurt (2011), an important study on economic literacy, aimed to develop a scale in order to detect economic literacy in their study. 355 university students participated in the study, and the structure validity results show that the scale has a four-factor structure explaining $52 \%$ of the total variance. The study reveals that the scale created is valid and reliable in measuring the economic literacy of university students. Mercan et al. (2012) in a branch affiliated to the Ministry of Transport with 93 people, $70 \%$ of whom are branch employees, it is seen that there is a differentiation in the sub-dimensions of economic literacy. This differentiation takes place in the dimension of individual economy use, in the way that those in the graduate range have higher levels of economic literacy compared to other education levels. Yasmin et al. (2014) conducted it on 200 students in universities in the southern part of Punjab, Pakistan. The results show that age, gender, father's education and student's education have a positive effect on the level of economic literacy. The results of Ünal et al. (2015) study, which investigated the economic literacy of the students of Tavşanli Vocational School through the use of credit cards, show that individuals with a relatively high level of economic literacy make more conscious and rational decisions. Dilek et al. (2016) investigated the level of economic literacy with the questionnaire they applied on 428 faculties, college and vocational school students studying at Kastamonu University. With the findings obtained, it was evaluated that the students have sufficient knowledge of economics.

In a study conducted on students of Amasya University Vocational School of Social Sciences, Bariş and Şeker (2017) showed that the level of economic literacy of students is moderate. The study also found that female students had lower knowledge levels than male students and that students with work experience had higher economic literacy levels than inexperienced students. Yayar and Karaca (2017) conducted a study on 397 public officials working in Tokat city centre, and it is seen that the economic literacy level of public employees is high and the results of economic literacy sub-dimensions differ depending on gender, age and income. Yildirim and Öztürk (2017) aimed to determine the level of economic literacy of social studies teachers and experts in their study. 116 social studies teachers and experts participated in the study, and as a result of the study, the level of economic literacy was insufficient. The study also investigated the views of social studies teachers and experts on Economic Education. It was found that individuals in the study supported that economic education should begin at the level of Secondary Education. Demirgil and Erilli (2018) as part of the study, which aims to determine the level of economic literacy in the city of Sivas, 2433 people were reached and surveyed. As a result of the study, it was concluded that the average score of the lower dimensions of economic literacy was moderate. Teyyare et al. (2018) investigated the level of economic and financial literacy of students of the Faculty of Economics and Administrative Sciences of Bolu Abant Izzet Baysal University. Although the results of the analysis differ between the levels of department, class, and academic achievement, it is found that the level of economic and financial literacy of students, in general, is sufficient. Dilek et al. (2019) investigated the effect of the level of economic literacy of the students of the Faculty of Economics and Administrative Sciences of Kastamonu university on entrepreneurial intent. The results are that economic literacy has a positive impact on entrepreneurial intent. Another study conducted on students (Özgür Güler \& Veysikarani, 2019) examined the level of economic literacy of students of the Institute of Social Sciences of the University of Çukurova. In the study, a questionnaire consisting of 34 questions was applied to 224 graduate students. The results show that the increase in the 
number of courses students take on economics and the frequency with which they follow the economy has a positive impact on the level of economic literacy.

Aviani et al. (2019) examined the effect of modernization, economic literacy, and social environment on students' consumption behaviors on 82 students. Findings obtained in the study show that modernity and economic literacy have a positive effect on student consumption behaviors. As'ad and Zulfikar (2020) investigated the economic literacy levels and potentials of the participants in their study on 513 students studying at a private university in Indonesia. As a result of the analysis, it was determined that the economic literacy level of the students was at a medium level. In addition, it was found that the macroeconomic literacy levels of the students were higher than their microeconomic literacy levels.

In the study of Martins and Veiga (2020) the relationship between basic economic literacy, economic performance and economic policies of the country was examined on 400 students at Minho University in Portugal. As a result of the study, it was revealed that economics education has a positive effect on students' economic literacy and the current economic performance of the country.

Gök (2020) examined the effect of economics education on the level of economic literacy on Selçuk University Vocational School of Social Sciences students. As a result of the survey study applied to 218 students, it was found that the economics literacy level of the students was approximately $71 \%$. In addition, it is seen that the economics courses students take in the study contribute positively to the level of economic literacy. Nizam et al. (2020) investigated the level of economic literacy with a survey conducted on 400 students selected from different educational institutions in Malaysia. As a result of the study, the results were obtained that the level of economic literacy is low at all educational levels and that household income and student's living space are important above the level of economic literacy.

According to the results obtained from the studies, demographic factors appear to affect the level of economic literacy. In addition, it is evaluated that economic education and the level of education of individuals can have an impact on the level of economic literacy.

\section{RESEARCH METHODOLOGY}

The study was conducted on public and private sector employees, self-employed, pensioners and students living in Turkey and aimed to determine the level of economic literacy of these people. The study will also investigate whether the level of economic literacy may vary by demographic characteristics, such as age, gender, marital status, and education level.

The economic literacy scale used in the current study was developed by Gerek and Kurt (2011). The scale consists of 34 items and a single dimension. The 34 items in question were measured as "Strongly Disagree (1)", "Disagree (2)", "Undecided (3)", "Agree (4)" and "Strongly Agree (5)". In other words, scoring between 1-5 was made for each item. While the lowest score of a participant is 34, the highest score is 170. In addition, 6 questions regarding gender, age, income, marital status, educational status and professions were asked in the study.

The universe of the study consists of individuals aged 18-65 living in Turkey. A total of 389 people were reached in the study, but data from 4 participants were not included in the analyses because they were missing or erroneous. Therefore, the study sample consists of 385 people. Since the economic literacy scale used in this study showed normal distribution, two 
of the parametric tests, the independent t-test and the one-way ANOVA test, were used. In other words, according to gender and marital status, the economic literacy score was measured by an independent t-test. The economic literacy score was measured by an independent one-way ANOVA test based on occupation, age, income and educational status.

\section{RESEARCH FINDINGS}

In this section of the study, the findings obtained from the analyses made in the current study regarding the economic literacy level of the individuals are presented.

In the study, a total of 385 people were reached to determine their economic literacy level. The demographic features of the participants are given in Table 1. As can be seen in the table, $57.1 \%$ of the participants are females and $43.9 \%$ of them are males.

As can be seen in Table 1, 81.26\% of the participants are in the age group of $18-25,12.5 \%$ are in the age group of $26-35,4.2 \%$ are in the age group of $36-50$ and $1.8 \%$ are in the age group of 51 and over. In addition, $84.7 \%$ of the participants are single and $15.3 \%$ of them are married.

Table 1. Demographic Features of the Participants

\begin{tabular}{|c|c|c|}
\hline & $\mathrm{f}$ & $\%$ \\
\hline \multicolumn{3}{|l|}{ Gender } \\
\hline Female & 220 & 57,1 \\
\hline Male & 165 & 42,9 \\
\hline \multicolumn{3}{|l|}{ Age } \\
\hline $18-25$ & 314 & 81,6 \\
\hline $26-35$ & 48 & 12,5 \\
\hline $36-50$ & 16 & 4,2 \\
\hline 51 and over & 7 & 1,8 \\
\hline \multicolumn{3}{|l|}{ Educational Level } \\
\hline Elementary School & 24 & 6,2 \\
\hline High School & 106 & 27,5 \\
\hline Associate's degree & 142 & 36,9 \\
\hline Undergraduate and Graduate & 113 & 29,4 \\
\hline \multicolumn{3}{|l|}{ Marital Status } \\
\hline Single & 326 & 84,7 \\
\hline Married & 59 & 15,3 \\
\hline \multicolumn{3}{|l|}{ Occupation } \\
\hline Private Sector & 33 & 8,6 \\
\hline Public Sector & 97 & 25,2 \\
\hline Self-Employed & 25 & 6,5 \\
\hline Retired & 4 & 1,0 \\
\hline Not Working & 226 & 58,7 \\
\hline \multicolumn{3}{|l|}{ Income } \\
\hline 0-1700 TL & 216 & 56,1 \\
\hline $1701-2500 \mathrm{TL}$ & 77 & 20,0 \\
\hline $2501-4000 \mathrm{TL}$ & 50 & 13,0 \\
\hline 4001-6000 TL & 24 & 6,2 \\
\hline $6001 \mathrm{TL}$ and Higher & 18 & 4,7 \\
\hline TOTAL & 385 & 100,0 \\
\hline
\end{tabular}


When the education level of the people within the scope of the research is examined, it is seen that $6.2 \%$ have primary education, $27.5 \%$ high school, $36.9 \%$ associate degree and $29.4 \%$ undergraduate and above education level. When the occupation distribution of the respondents is examined, it is seen that $58.7 \%$ do not work in any job, $1 \%$ is retired, $6.5 \%$ are self-employed, $25.2 \%$ are public employees and $8.6 \%$ are private-sector employees. In addition, it is understood that $56.1 \%$ of the participants in the study earned an income of 0 1700 TL, 20\% 1700-2500 TL and 4.7\% 6001 and higher.

Table 2. Descriptive Statistics regarding Economic Literacy

Dimension Mean $\quad$ Std. Deviation

Table 2 shows that the arithmetic average of responses given by individuals to survey questions aimed at measuring the level of economic literacy is 121,693. The survey used in the study consists of 34 questions, and as a result of the survey, the economic literacy score is obtained as a value between 34 and 170. Accordingly, the level of economic literacy of the participants in the study was 71.58 out of 100 .

Table 3. Comparison of the Economic Literacy Level on the Basis of Gender

\begin{tabular}{lccccc} 
& Gender & $\mathrm{f}$ & Mean & Std. Deviation & T-test Sig. \\
& & & & & \\
\cline { 2 - 5 } & Female & 220 & 120.109 & 24.157 & 0.183 \\
Literacy Level & Male & 165 & 123.806 & 30.144 & \\
\hline
\end{tabular}

Source: Author

Economic literacy success averages according to the gender of the participants are shown in Table 3. According to the findings obtained; There is no statistically significant difference in economic literacy level according to the gender of the participants ( $p>0.05$ ). In other words, as a result of the analysis, it is understood that the economic literacy levels of men and women are similar.

Table 4. Comparison of the Economic Literacy Level on the Basis of Marital Status

\begin{tabular}{lccccc} 
& Marital Status & $\mathrm{f}$ & Mean & Std. Deviation & T-test Sig. \\
\cline { 2 - 5 } & & & & & \\
Economic & Single & 326 & 121.162 & 27.378 & 0.364 \\
Literacy Level & Married & 59 & 124.627 & 24.181 & \\
\hline
\end{tabular}

Source: Author

Table 4 contains the results of the economic literacy levels according to the marital status of the participants in the research. According to these results, it is understood that there is no statistically significant difference in the economic literacy level according to the marital status 
of the participants ( $\mathrm{p}>0.05$ ). Accordingly, it is considered that economic literacy levels are similar according to the marital status of the participants.

Table 5. Age-Based Economic Literacy Level

\begin{tabular}{lccccc}
\hline & Age & $\mathrm{f}$ & Mean & Std. Deviation & Anova Sig. \\
Economic & $18-25$ & 314 & 121.076 & 26.707 & \\
\cline { 2 - 6 } Literacy Level & $26-35$ & 48 & 123.875 & 28.597 & 0.621 \\
& 36 and over & 23 & 125.565 & 26.745 & \\
& & &
\end{tabular}

Source: Author

Average levels of economic literacy according to the age of the study participants are presented in Table 5. The results in Table 5 show that the level of economic literacy success in all age groups is the same according to the age of participants ( $>0.05)$. In other words, it is understood that the level of economic literacy of participants in different age groups is similar to each other.

Table 6. Comparison of the Economic Literacy Level according to Income Level

\begin{tabular}{lccccc} 
& Income & $\mathrm{f}$ & Mean & Std. Deviation & Anova Sig. \\
\cline { 2 - 6 } & $1700 \mathrm{TL}$ and less & 216 & 120.333 & 24.491 & \\
Economic & $1701-2500 \mathrm{TL}$ & 77 & 121.039 & 30.625 & \\
Literacy Level & $2501-4000 \mathrm{TL}$ & 50 & 123.220 & 30.286 & 0.375 \\
& 4001 and higher & 42 & 128.071 & 27.353 & \\
\hline
\end{tabular}

Source: Author

In Table 6, the level of economic literacy of the participants was compared according to their income status. When the results of the analysis are examined, it is seen that the level of economic literacy does not differ statistically significantly according to the income status of the participants $(\mathrm{p}>0.05)$. There is no difference in the level of economic literacy in terms of income status between participants with income of $\$ 1700$ and below and participants with income of $\$ 4001$ and above at the two ends of the income groups.

Table 7. Comparison of the Economic Literacy Level according to Educational Level

\begin{tabular}{lccccc}
\hline & $\begin{array}{c}\text { Educational } \\
\text { Level }\end{array}$ & $\mathrm{f}$ & Mean & Std. Deviation & Anova Sig. \\
\cline { 2 - 6 } & $\begin{array}{c}\text { Elementary } \\
\text { school }\end{array}$ & 24 & 110.416 & 25.318 & \\
Economic & $\begin{array}{c}\text { High school } \\
\text { Literacy Level }\end{array}$ & 106 & 118.037 & 29.314 & \\
& $\begin{array}{c}\text { Associate's } \\
\text { degree } \\
\text { Undergraduate } \\
\text { and graduate } \\
\text { degree }\end{array}$ & 142 & 122.303 & 25.313 & $\mathbf{0 . 0 1 6}$ \\
& 113 & 126.743 & 25.946 & \\
\hline
\end{tabular}


Table 7 shows results in which participants' economic literacy success levels are compared according to their educational level. According to these results, there is a significant difference between the average achievement of economic literacy of the level of Education $(p<0.05)$. A study of the result of the Post Hoc TUKEY test shows that individuals with undergraduate education have higher levels of economic literacy than other levels of Education. It is understood that the economic literacy levels of individuals with associate degree education level are higher than those with primary education level. The results obtained according to the level of education lead to an increase in the level of education to an increase in the level of economic literacy.

Table 8 shows the comparison of the participants' economic literacy levels according to their occupations. When the results of the analysis are examined, it is seen that the participants' economic literacy level varies significantly depending on occupation $(p>0.05)$. In other words, the economic literacy level of the public employees is higher than those of the participants from the other occupational groups.

Table 8. Comparison of Economic Literacy Levels according to the Occupations

\begin{tabular}{|c|c|c|c|c|c|}
\hline \multirow{5}{*}{$\begin{array}{l}\text { Economic } \\
\text { Literacy Level }\end{array}$} & Occupation & F & Mean & Std. Deviation & Anova Sig. \\
\hline & Public sector & 33 & 135.424 & 21.308 & \multirow{4}{*}{0.006} \\
\hline & Private sector & 97 & 122.639 & 29.976 & \\
\hline & Self-employed & 25 & 112.480 & 32.358 & \\
\hline & Not working & 226 & 120.128 & 25.061 & \\
\hline
\end{tabular}

Source: Author

The findings obtained in the study indicate that the level of economic literacy is higher according to the education level Mercan (2012), Yasmin et al. (2014), Teyyare et al. (2018) comply with their studies. In our study, the results at the level of economic literacy according to professions are in line with the result of the higher economic literacy level of public employees in the study of Yayar and Karaca (2017) compared to other occupational groups. On the other hand, the results of our study are not compatible with the study conducted by Yildirim and Öztürk (2017) on social studies teachers. The reason for the inconsistency of the results is considered to be related to the professions of the teachers.

In the results obtained within the scope of our study, it is seen that there is no statistically significant difference in economic literacy level according to gender, marital status, age and income level. However, there are statistically significant differences in economic literacy levels according to education level and occupational groups. Appropriate policies can be developed by evaluating these results with differentiation specific to Turkey.

\section{DISCUSSION}

Studies are increasingly examining the level of economic knowledge of stakeholders involved in the economy. As part of the financial liberalization policies of countries, the policies implemented by Islamic countries in order to attract investors reveal the need to investigate Islamic financial markets. Studies such as Bekereci et al. (2019), Altundere Doğan (2020), Kevser and Doğan (2021) have investigated the level of Islamic financial literacy. However, 
since these studies are limited to the field of Islamic finance, general economics does not provide sufficient information on literacy. On the other hand, Acaravci and Bediroglu (2019) and Bagci and Arabaci (2019), which investigate the level of financial literacy of individuals in Turkey, especially about the global financial market, which has grown significantly over the past thirty years, do not seem to offer an idea of the overall society in which the studies are conducted on specific groups of students. However, because the Dogan (2019) study was conducted by surveying 2300 people living in Turkey, it is estimated that society can give an idea of the overall level of financial literacy.

In recent years, the economic contraction caused by the 2009 Mortgage crisis and the 2020 corona virus outbreak has been effective in the economy of all countries. This has increased interest in economic developments and made it more important to measure the level of economic literacy. But in this direction, Gerek and Kurt (2011), Yasmin et al (2014), Ünal et al. (2015), Dilek et al. (2016), Bariş and Şeker (2017), Teyyare et al. (2018), Dilek et al. (2019), Özgür Güler and Veysikarani (2019), Aviani et al. (2019), Martins and Veiga (2020), Gök (2020), Nizam et al. (2020) studies are usually conducted on the students. It is believed that the results of these studies are limited to the educational levels and attitudes of the students concerned and do not offer information about them to the general community. Mercan et al. (2012) and Yayar and Karaca (2017) investigating the economic literacy level of public employees make different contributions to the literature. However, since these studies are limited to public employees only, they do not provide the opportunity to make comparisons about other occupational groups.

Our study is different from other studies as it covers individuals with different ages, professions and income levels within the scope of the issues stated about the studies. The results showing that economic literacy increased due to the increase in the level of education obtained in our study (Mercan, 2012; Yasmin et al., 2014; Teyyare et al., 2018). In addition, the result that the economic literacy level of public employees is higher than other occupational groups is in line with the study of Yayar and Karaca (2017).

\section{CONCLUSIONS}

Economics seeks solutions to meet the infinite needs with scarce resources. In this sense, the economy basically focuses on three problems. It is to benefit from all of the production factors expressed as the first full use problem. For example, unemployment occurs when labor force, one of the factors of production, is not fully utilized. The second problem is whether the existing resources are used effectively for the needs of society. In order to solve this problem, individuals, businesses, the government have to decide how to use limited resources. The third problem is which goods and services will be produced and how much to meet the needs of the society. If the right decision is not made within the scope of this problem, the shortage of some goods will suffer and transportation of these goods will be difficult (Dinler, 2010). Economic literacy is a very useful element for individuals, businesses and policymakers who make many economic decisions every day in the face of these problems. Rational individuals will choose by analysing and interpreting economic events, evaluating and examining public policies. The increase in the number of individuals who make the right economic decisions will facilitate the success of policies implemented by policymakers to increase welfare (As'ad and Zulfikar, 2020). On the other hand, although domestic conditions are important in the economic decisions of individuals, it is important to follow them in their developments in the world. The decisions taken by individuals living in developing countries in terms of consumption and savings can have an impact on the country's macroeconomic 
indicators (Tekbaş,2019). In this sense, determining the economic literacy level of individuals in Turkey, which has important economic goals in recent years, is important for policymakers. This study aims to determine the economic literacy level of individuals with different demographic characteristics living in different provinces in Turkey. In this direction, a questionnaire was applied to 385 people, including public, private sector and self-employed workers, retirees and students. The findings of the study show that the literacy level in Turkey is slightly above the middle. It is understood from the findings that the occupational group with the highest economic literacy level belongs to the public sector and the lowest level belongs to the self-employed workers. Another important result obtained as a result of the research is; it is the difference in the level of economic literacy according to the level of education. Accordingly, it has been concluded that individuals with undergraduate and graduate education have the highest level of economic literacy, while individuals with primary education have the lowest level of economic literacy compared to other educational levels.

In summary, since there is an important relationship between economic literacy level and education level, economic education should be expanded. The success of the economic policies implemented by the governments is possible with the correct understanding of the policies by individuals and businesses. It is seen that the development of an economic platform for everyone, which has been put into practice by the Central Bank of the Republic of Turkey since the beginning of 2018, has made a significant contribution to the knowledge level of the people concerned in this field. In this respect, it is considered that providing basic economics courses as elective courses starting from undergraduate secondary education will be beneficial to increase the level of economic literacy. It is considered that it would be beneficial for public institutions such as the Central Bank, Ministry of Economy and Development to make the necessary planning and support the relevant departments of universities with materials suitable for today's distance education platforms in order to popularize economics education. The success of the economic policies implemented by the governments is possible with the correct understanding of the policies by individuals and businesses. It is also important to increase training and consultancy activities for occupational groups such as self-employed workers with low levels of economic literacy.

This study investigating economic literacy in the Turkish sample has some limitations. First, the results obtained should be evaluated in terms of the year 2021 and Turkey. In addition, a 34-question economic literacy scale was used. Different results can be obtained in studies conducted with different samples or with different economic literacy scales. In future studies, similar studies can be conducted with different samples and compared with the results of this study.

\section{REFERENCES}

Acaravci, S.K. \& Bediroğlu, K. (2019). Financial Literacy: Application on Hatay Mustafa Kemal University, Journal of Business and Economics Studies (JBES), 7(2), 30-51.

Altundere Doğan, M. (2020). Islamic Financial Literacy and its Effect on Financial Choices. BRSA Journal of Banking and Financial Markets, 14(1), 69-98.

As'ad, M. \& Zulfikar, R. (2020). Economic Literacy Levels: A Case Study in Indonesian University. Econder International Academic Journal, 4(1), 190-202.

Aviani, E. \& Hardinto, P. (2020). The Effect of Modernity, Economic Literacy, and Social Environment on Consumption behavior of Senior High School Students. Classroom Action Research Journal (CARJO), 3(3), 102-109. 
Aydemir, C. \& Mehmet, K.A.Y.A. (2007). The Globalization Concept and Its Economical Side. Electronic Journal of Social Sciences, 6(20), 260-282.

Bağci, H. \& Arabaci, S.M. (2019). Determination of Financial Literacy Level and Factors Affecting Financial Literacy, Business \& Management Studies: An International Journal, 7(3), 68-88.

Bariş, S. \& Seker, H. (2017). Economic Literacy: A Research on Amasya University. Finance Political \& Economic Commentary, 54(624), 79.

Bekereci, N.E., Ayriçay, Y. \& Dündar, Kök (2018). Islamic Financial Literacy: A Field Research in Kahramanmaraş Sütçü İmam University. Pamukkale University Journal of Social Sciences Institute, (33), 45-60.

Demirgil, B. \& Erilli, N.A. (2018). A Research on the Determination for the Level Of The Economics Literacy: Case Of Sivas. 7th International Symposium from the Ideal to the Reality Society, Politics and Economy. Malatya, Turkey.

Dilek S., Keskingöz, H., Nergiz, E. (2019). The Impact of Economic Literacy on Entrepreneurship Intention, Third Sector Social Economic Review, 54(1), 89-107.

Dilek, S., Küçük, O. \& Eleren, A. (2016). Economic Literacy of Kastamonu University Students, Itobiad: Journal of the Human \& Social Science Researches, 5(7).

Dinler, Z. (2010). Introduction to Economics, Bursa, Turkey: Ekin Publication

Doğan, M. (2019). Survey of Financial Literacy in Turkey, Third Sector Social Economic Review, 54(4), 1602-1620

Gerek, S. ve Kurt, A.A. (2011). Economic Literacy Scale: Validity-Reliability Study, Uludă Journal of Economy and Society, 3 (1), 59-73.

Gök, D. (2020). A Research on Determination of the Effect of Economy Education on Economic Literacy Level. Gümüşhane University Journal of Social Sciences Institute, 11 (2), 430-447.

Kahya, C. \& İmamoğlu, İ.K. (2015). Ekonomio kuryazarliğinin girişimcilik Niyeti üzerindeki rolü. The Journal of Academic Social Science Studies, 39, 139-156.

Kevser, M. \& Doğan, M. (2021). Islamic Financial Literacy and Its Determinants: A Field Study on Turkey. Journal Transition Studies Review, 28(1), 91-120.

Martins, J.O. \& Veiga, L.G. (2019). Undergraduate students' economic literacy, knowledge of the country's economic performance and opinions regarding appropriate economic policies. Nucleo de Investigacao Em Politicas Economicas e Empresariais 15.

Mercan, N., Oyur, E., Altinay, A. \& Aksanyar, Y. (2012). An Empirical Resource on Economic Literacy. Journal of Economic Sciences, 4(2), 109-118.

Nizam, N.F.M., Sieng, L.W. \& Sulaiman, N. (2020). Economic Literacy among Students in Malaysia. Geografia-Malaysian Journal of Society and Space, 16(3).

Özgür Güler, E. \& Veysikarani, D. (2019). An Empirical Research on Economic Literacy, Journal of the Cukurova University Institute of Social Sciences, 28(1).

Tekbaş, M. (2019). Relationship between Economic Growth and Globalization in The BRICS-T Countries. Research of Financial Economic and Social Studies, 4(3), 397-412.

Teyyare, E., Ayyildiz, B., Dirican, H., Zivali, B. S. \& Renkli, B. (2018). A Study on Economic and Fiscal Literacy: The Case of Abant Izzet Baysal University Faculty of Economics And Administrative Sciences. The International Journal of Economic and Social Research, 14 (1), 99-120

Ünal, S., Düğer, Y. S. \& Söylemez, C. (2015). The Impact of Economic Literacy and Attitude Toward Credit Card Usage on Rational Use of Credit Cards: The Case of Dumlupinar University Tavşanli Vocational College. Eskişehir Osmangazi University Journal of Economic and Administrative Sciences. 10(1), 31-52. 
Yasmin, F., Kouser, R. \& Ahmad, W. (2014). Determinants of economic literacy at university level: a case of Pakistan. Pakistan Journal of Commerce and Social Sciences (PJCSS), 8(3), 914-924.

Yayar, R. \& Karaca, Ö.E. (2017). Economic literacy levels of public officers in Turkey. Pakistan Journal of Commerce and Social Sciences (PJCSS), 11(1), 49-65.

Yeldan, E. (2016). Turkish economy in the globalization process: distribution, accumulation and growth. İstanbul, Turkey: Communication Publications

Yildirim, K. (2019) Introduction to Economics, Kiliçaslan Y. \& Esen E. (Ed.) Scope of macroeconomics and basic macroeconomic variables (pp.77-101), Eskişehir, Turkey: Anadolu University publications.

Yildirim, G. \& Öztürk, C. (2017). An Investigation of the Views of Field Experts and Teachers related to Economic Literacy and Its Education. Erciyes Journal of Education (EJE). 1(2), 1-22. 